Relations industrielles

Industrial Relations

\title{
Culture and the Labour Market by Siobhan AUSTEN, Northampton, Mass.: Edward Elgar Publishing, 2003, 152 pages, ISBN 1-84376-317-6.
}

\section{Paolo Ghinetti et Claudio Lucifora}

Volume 59, numéro 4, automne 2004

URI : https://id.erudit.org/iderudit/011343ar

DOI : https://doi.org/10.7202/011343ar

Aller au sommaire du numéro

Éditeur(s)

Département des relations industrielles de l'Université Laval

ISSN

0034-379X (imprimé)

1703-8138 (numérique)

Découvrir la revue

Citer ce compte rendu

Ghinetti, P. \& Lucifora, C. (2004). Compte rendu de [Culture and the Labour Market by Siobhan AUSTEN, Northampton, Mass.: Edward Elgar Publishing, 2003, 152 pages, ISBN 1-84376-317-6.] Relations industrielles / Industrial Relations, 59(4), 805-806. https://doi.org/10.7202/011343ar

Tous droits réservés (C) Département des relations industrielles de l'Université Laval, 2004
Ce document est protégé par la loi sur le droit d'auteur. L'utilisation des services d’Érudit (y compris la reproduction) est assujettie à sa politique d'utilisation que vous pouvez consulter en ligne.

https://apropos.erudit.org/fr/usagers/politique-dutilisation/ 


\section{Culture and the Labour Market}

by Siobhan Austen, Northampton, Mass.: Edward Elgar Publishing, 2003, 152 pages, ISBN 1-84376-317-6.

Stimulated by the results of psychological and sociological studies, as well as by results of experimental analysis, this book aims at providing theoretical foundation, examples as well as new empirical evidence about the effects of cultural aspects - such as social norms, beliefs, reciprocity, morals and community conventions - on individual economic behaviour and outcomes in the labour market.

The author begin by criticizing the assumptions made by mainstream neoclassical models - self-interested agents with exogenous and independent preferences - and proceed to discuss the attempts to incorporate fairness and equity considerations into agents' judgments and behaviours. Whilst these aspects are increasingly studied by economists and industrial relations scholars, still the literature has been until now quite heterogeneous, and a clear description of the notion of culture and of its relationships with the economic environment is almost lacking.

In order to address these issues, the first part of the book (chapters two to four) develops a careful analysis of the meaning of culture, and reviews some alternative theories advanced in the economic literature to model the interactions between cultural effects and economic outcomes.

The theoretical material provides a general framework for the second part of the book (chapters five to eight) that contains a number of empirical studies based on international surveys. As compared to the theoretical analysis, these are more focussed and investigate how individual fairness and equity beliefs affect a number of labour market issues - such as skilled/unskilled differentials, earnings inequality and minimum wages - in a number of Western and Post communist countries.
To familiarize the reader with key concepts, chapter two presents a very interesting discussion about the meaning of culture, its possible characterizations and the ways through which cultural expressions shape economic outcomes and the behaviour of economic agents. It is argued that culture affects individuals through two main channels: first, by influencing individual preferences - which are assumed not to be exogenous - and, secondly, through social norms, beliefs, and morality that modify and regulate individuals' actions, whose welfare is influenced not only by pure self-interest, but also by equity, equality and distribution concerns.

The nature of the "regulatory effect" of social norms on individual behaviour is investigated in more detail in chapter three, which presents the contributions developed in the economic literature to model the relationships between equityguided and self-interested behaviour. Especially relevant for the theoretical and empirical analysis is the review of equity-based efficiency wage models, in which adherence of individual behaviour to several social norms - fairness for the definition of wages, reciprocity norms to protect the income of low paid - is powerful enough to modify wage levels, wage differentials between groups and labour market outcomes at the aggregate level.

Chapter four builds on these ideas and presents a model that extends the standard Akerlof's efficiency wage model allowing for fairness judgments not on the wage level, but, instead, on the skill-based wage differential. Since fairness affects the level of effort and the workers' desire to preserve wage relativities, employers may have no incentive to adjust wages according to changed economic conditions. 
The first three chapters of the second part of the book constitute the bulk of the empirical analysis and use the 1987 and 1992 waves of the International Social Science Survey Program (ISSP), a data set that records information on skill differentials for fourteen countries.

Chapter five tests the prediction of the equity-based model presented in previous chapters, i.e., that fairness judgments are based on skill-based wage differentials. The main result is that perceptions about skill differentials greatly affect fairness concerns in all the countries considered. Moreover, attitudes persist and tend to adapt very slowly to changed economic conditions.

Chapter six moves from equity to equality considerations in the analysis of wage differentials. The focus in on international differences in attitudes to wage inequality - defined as the ratio between high-status and low-status occupations. The author finds that, across countries, perceived levels of inequality have great influence on beliefs and cultural attitudes about the legitimacy of wage disparity: social acceptance of high levels of inequality is therefore associated with the experience of large differences in wages between the top and the bottom line, although in some countries this match is not perfect. The author also finds that "norms of inequality are not perfectly fluid. For example, [...] international differences in attitudes towards inequality persisted despite the pressures of globalization towards more uniform wage structures" (page 88). In other words, changes in wage structures due to external international pressures could be smoothed by existing wage-setting regimes and cultural environments.

Limited by the availability of data for two time periods (1987-1992) and for a sub-sample of six countries, a more detailed analysis of the relationship between cultural changes and wage structure modifications is presented in chapter seven. Main results show that in each country the tolerance of earnings inequality has increased over time. Interestingly, this result is more evident for transition economies, such as Hungary and Poland, suggesting that restructuring processes and opening to global markets increase the social acceptance of disparities between different classes of workers. However, the mapping between perceived and legitimate levels of inequality is not perfect and the increase in wage disparities over the period 1987-1992 produced lower levels of satisfaction within the workforce.

Chapter eight turns attention to social norms of distribution and examines the relationship between the application of minimum wages and the judgment about the legitimacy of protecting low paid income in Australia. The findings suggest that existing minimum wage legislation is indeed positively associated to the perceived legitimacy of measures supporting the income of the low paid. In addition, this attitude is unevenly distributed in the population according to individual characteristics, such as union membership and political orientation.

As its major merit, this book uses rigorous, clear and intriguing theoretical foundations to derive testable implications for an innovative empirical analysis of the effects of social norms on wage differences. In addition, the use of a large-scale International Survey is valuable because it allows comparisons across countries that differ in economic, cultural and social aspects. Although many scholars would be probably more cautious than the author in interpreting the relationship between perceptions of wage differences and attitudes on wage differences as a causal effect, we recommend this book for its thorough, original and highly readable documentation concerning a topic that should be at the core of interest to industrial relations and labour economics scholars.

Paolo Ghinetti and

Claudio Lucifora

Università Cattolica di Milano 